\title{
特集／泌尿器科とレーザー
}

\section{泌尿器科における共焦点型レーザー顕微鏡の応用 Applications of the confocal laser microscope for urology}

\author{
平川真治 ${ }^{a}$, 宮川征男 ${ }^{a}$, 飯野晃啓 ${ }^{b}$ \\ ${ }^{a}$ 鳥取大学医学部泌尿器科 \\ 同解剖学
}

\author{
Shinji HIRAKAWA a, Ikuo MIYAGAWA ${ }^{a}$ and Akihiro IINO ${ }^{b}$ \\ Departments of 'Urology and 'Anatomy, Faculty of Medicine Tottori University, \\ Nishimachi, Yonago 683
}

\begin{abstract}
要 旨
最近, 当科では染色や固定の不要な共焦点型レーザー顕微鏡（CLM）を血尿患者と男性不 妊症患者に特に応用している。今回 31 例の血尿患者の尿を採取した。 31 例中 23 例が泌尿器科疾 患，8例が系球体性疾患の患者だった。尿中の变形赤血球と正常赤血球はCLM で観察すると， きわめて形態学的に差がみられた。CLMによる泌尿器科疾患に対する感度と特異度は各々 100\%，95.7\%，一方，系球体性疾患に対する感度と特異度は各々100\%，87.5\%であった。

27例の正常男性と14例の男性不妊症患者について，精液を採取して CLM で観察したところ， 正常男性と男性不娃症患者の精子にはいくつかの形態学的な差がみとめられた。良い精子は頭 部が㹟く、中片が長く、頭部のアクロゾーム領域が広いことが推測された。一方，3例の血精 液症患者の精液中の赤血球は CLM で正常赤血球だった。

以上の結果より，CLM は尿中赤血球や精子の形態学的評価をより簡便かつ容易にするもの 亡思わ机る。CLM は血㲾患者の有力な補助的彭断法になりうると考元られ, また男性不妊症 の研究に役立つものと思われる。

キーワード：共焦点型レーザー顕微鏡, 血尿, 男性不妊症
\end{abstract}

\begin{abstract}
Recently, the confocal laser microscope (CLM) has been used in our department, particularly for patients with hematuria and male infertility, without requiring fixation and staining. In this study, urine specimens from 31 patients with hematuria were collected. Twenty three patients had urological disease and 8 had glomerular disease. The CLM of the urine specimens showed a marked morphplogical difference between dysmorphic and isomorphic erythrocytes. The sensitivity and specificity for urological disease by CLM were $100 \%$ and $95.7 \%$, whereas those for glomerular disease were $100 \%$ and $87.5 \%$.
\end{abstract}

Semen specimens from 27 fertile men and 14 infertile men were collected. The sperm showed some morphplogical difference between fertile men and infertile men 
by the CLM. It was supposed that the good sperm had narrow sperm head. long sperm midpiece and wide acrosomal region of sperm head. By the way, semen specimens from 3 patients with hematospermia were collected. The red-blood-cells in semen were isomsrphic by the CLM.

From these results, it seems like that the CLM makes it simpler and easier to evaluate the morphology of the erythrocyte in urine and sperm. The CLM can be a good assistant diagnostic modality for patients with hematuria and investigative modality for male infertility.

Key Words : confocal laser microscope, hematuria, male infertility

\section{1. 目 的}

最近，当科では，無固定，無設定で観察でき，画像が 鮮明で，操作が簡単で，ビデオ収録も可能なリアルタイ ム共焦点型レーザー顕微鏡を用い，血尿患者の尿中の赤 血球形態をルーチンに観察し，血尿の有力な補助診断法 の一つとして使用しているのでリー3)，そ扎について報 告する。

また，男性不妊症患者の精子形態に関する研究につい ても、このレーザー顕微鏡を用いているし"，さらに， 血精液症患者の赤血球形態をレーザー顕微鏡で観察して みたので，それらについてもあわせて報告する。

\section{2. 対象および方法}

最近，当科に受診した血尿患者31例，血精液症患者 3 例および男性不妊症患者 14 例を対象亡し，自然妊㔔の あった正常男性27例を男性不妊症患者の対照亡し比較検 討とした。

方法としては，血尿患者では新鮮尿 $10 \mathrm{ml}$ 学1500回転， 5 分間遠沈し，その沈椬を一滴，鏡張り（アルミ蒸着） してあるスライドグラスの上に落とし，無固定，無染色 で，レーザー顕微鏡を用いて観察した。肉眼的血尿の場 合は遠沈せず，そのままスライドグラスの上に落とした。 レーザー顕微鏡としてはレーザーデック社製の1 LMOI か1LMllを使用した。当科ではこのレーザー顕微鏡に 上る尿中赤血球の形態診断をレーザー検尿と呼んでいる。 尿中赤血球の形態をTVモニター上で観察する訳である が，モニター上の倍率は、1 LMOlと1 LMllでそれぞ れ最大 7200 倍か6400倍だが, 1440倍か1280倍(対物20倍)， あるいは3600倍か3200倍 (対物50倍) が，尿中赤血球の 観察に適している。排尿後 1 〜 時間以内の新鮮尿でな るべく検查するように試みたが，やむをえない場合は 4 ${ }^{\circ} \mathrm{C}$ で冷所保存を行った。Thielら”? の分類にもとづいて， 尿中赤助球の形態を判定したが，偏見によらわれないよ
うに，患者に関する情報はなしで，できるだけ二人でぺ アになって判定するように心がけた。30～50個〈最低30 個）の赤血球の形態老判定し，その検体の血尿由来在推 定した。血尿由来の判定基準として, 石原ら" ${ }^{6}$ の報告に もとづき，尿中変形赤血球が70\%以上を占める場合を約 球体性 (变形型, dysmorphic), 正常赤血球が70\%以 上の場合を韭系球体性（正常型，isomorphic），両者 の中間を混合性 (mixed) と判定した。一検体の評価 に要する時間は通常 5 分以内であった。

一方，精子の形態診断の場含は，手滛によって採取し た精液を30〜60分間室温に放犆し，均質化したところで， その一滴を鏡張りしてあるスライドグラスの上におとし． カバーグラス在かけ，哭固定，無染色でレーザー㩆微鏡 で観察し，ビデオテープに収録したものをコンピュー ターを用いて画像解析した。血精液症の場合も同様に精 液をレーザー顕微鏡で観察し，精液中の赤血球の形態を 尿中赤血球の形態分類にもとづいて判定した。

\section{3. 成 績}

\section{1）血尿患者}

まず，レーザー検求における尿中正常赤血球像と变形 赤血球像の例を図に示す（図 1，図 2)。また，1 LMll では図 3 に示すように赤血球などの検体の微小寸法を測 定することも可能である（図 3 ）。

血尿患者31例の内訳は23例が泌尿器科疾患，8例が采 球体性疾患の患者であっだ。系球体性疾患 8 例中，新鮮 例 6 例，再燃例 2 例だった。レーザー検尿では，系球体 性疾患 8 例中 7 例 $(87.5 \%)$ が糸球体性のパターンを示 し，1例が泿合性上判定された。一方，泌永器科疾患23 例中22例 $(95.7 \%)$ が非糸球体性のパターンを示し.1 例が混合性と判定された（表 1 )。レーザー検尿の糸球 体性疾患に対する感度は100\%，特異度は87.5\%であり， また泌尿器科疾患に対する感度は100\%，特異度は95.7 


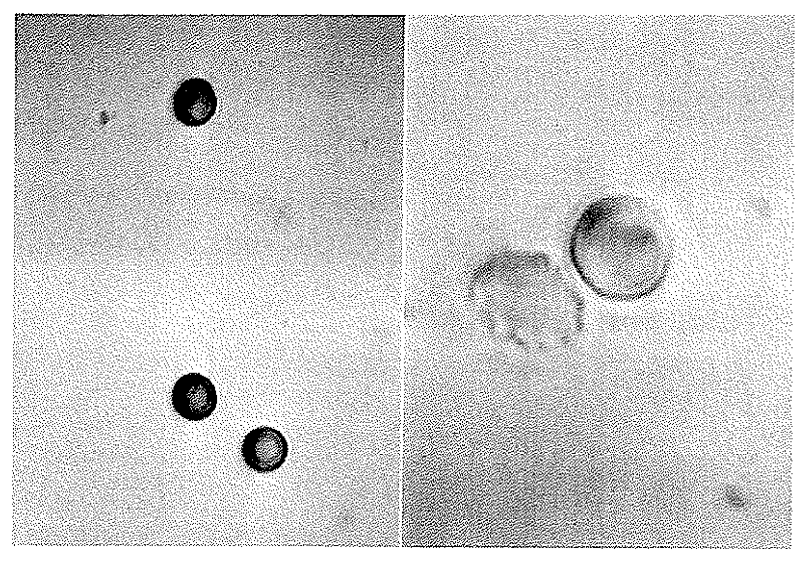

図 1 レーザー顕微鏡でみた尿中正常赤血球像 左：1440倍, 右：3200倍

(膀胱腫演症例)

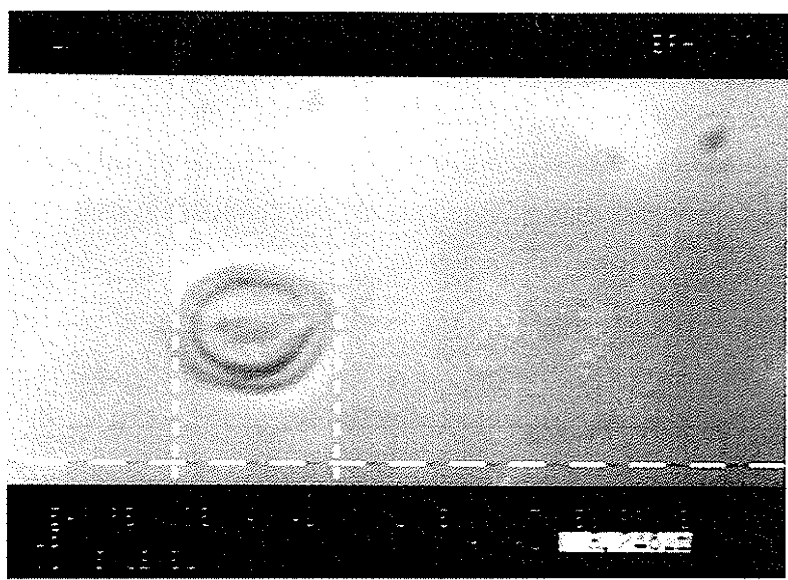

図 3 1 LMIIによる尿中赤血球の長径計測 3200 倍 前立腺肥大症症例

表 1 レーザー検尿の結果

\begin{tabular}{lcccr}
\hline diagnosis & \multicolumn{4}{c}{$\begin{array}{c}\text { morphology of urinary RBC } \\
\text { dysmorphic }\end{array}$} \\
& 7 & & & \\
\hline $\begin{array}{l}\text { glomerular } \\
\text { disease }\end{array}$ & 7 & & & 8 \\
\hline $\begin{array}{l}\text { urological } \\
\text { disease }\end{array}$ & & 22 & 1 & 23 \\
\hline \multicolumn{1}{c}{ total } & 7 & 22 & 2 & 3 \\
\hline
\end{tabular}

\%であった（表 $2 ， 3 ） 。$

\section{2) 男性不妊症患者}

レーザー顕微鏡でみた正常精子像と異常精子像の例を 図に示す（図 4，5）。男性不妊症患者では, 当科から すでに報告したように”，精子頭部の最大幅が $3.4 \mu \mathrm{m}$ (mean) と正常男性の3.1 $\mu \mathrm{m}$ に比べて有意に広く $(\mathrm{p}<0.05)$, 精子中片の長さは $4.2 \mu \mathrm{m}$ 之正常男性の

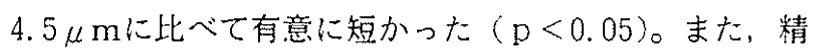
子頭部のアクロゾーム領域の頭部全体表面に占める割合 は男性不妊症でやや少ない傾向にあった。一方, 精子頭

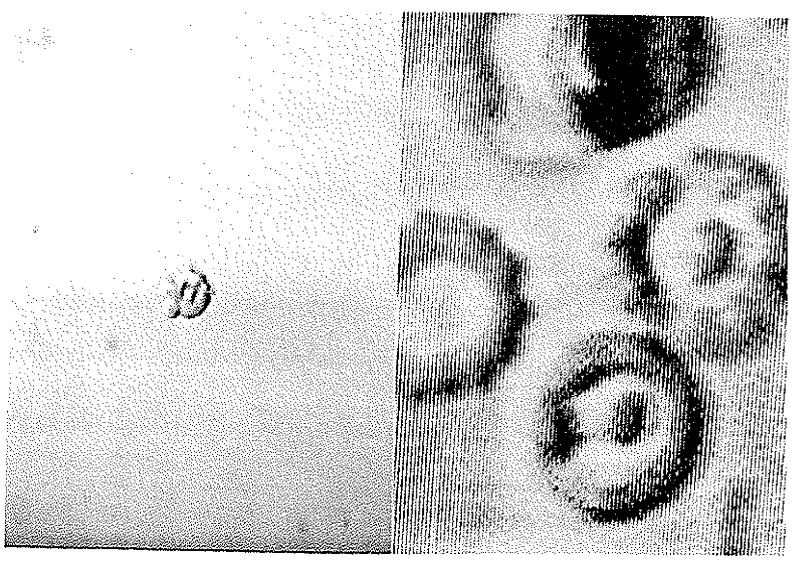

図 2 レーザー顕微鏡でみた尿中変形赤血球像 左 : 1440倍, 右 : 6400倍

(㹂炎症例)

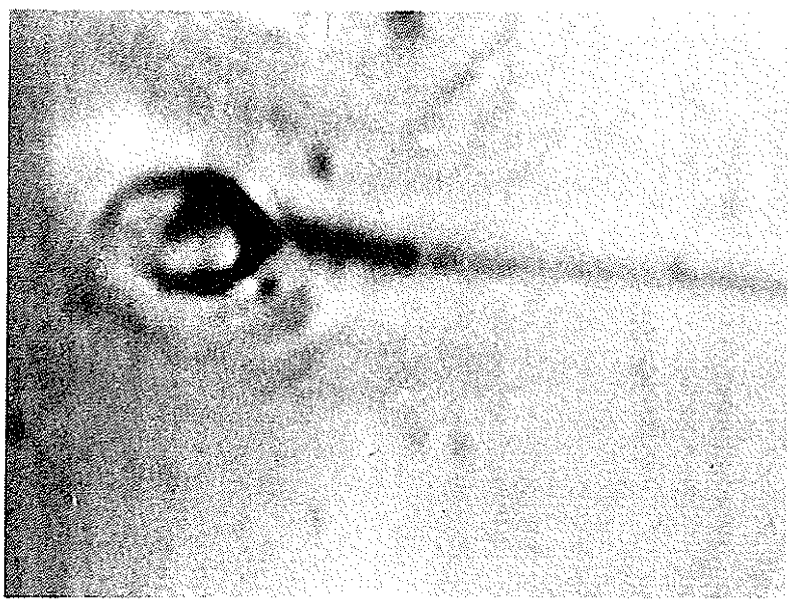

図 4 レーザー顕微鏡でみた正常精子像

表2 杀球体性疾患に対する感度と特異度

\begin{tabular}{c|c|ccc}
\hline \multicolumn{2}{l|}{} & positive & negative & total \\
\hline glomerular & + & 7 & 1 & 8 \\
\cline { 2 - 5 } disease & - & 0 & 23 & 23 \\
\hline \multicolumn{1}{c}{ total } & 7 & 24 & 31 \\
\hline
\end{tabular}

positive $=$ dysmorphic pattern

negative $=$ isomorphic + mixed pattern sensitivity $=100 \%$, specificity $=87.5 \%$

表3 泌尿器科疾患に対する感度と特異度

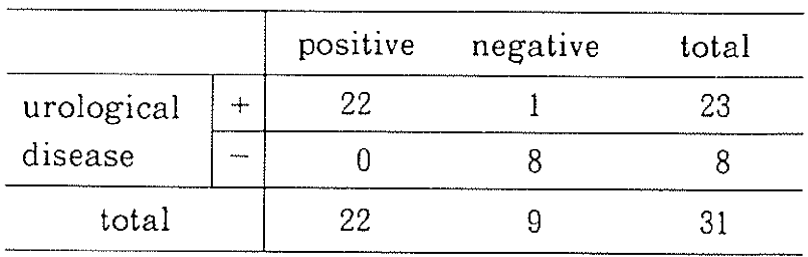

positive $=$ isomorphic pattern negative $=$ dysmorphic + mixed pattern sensitivity $=100 \%$, specificity $=95.7 \%$

部の最大長は男性不妊症患者之正常男性で差が認められ なかった。 


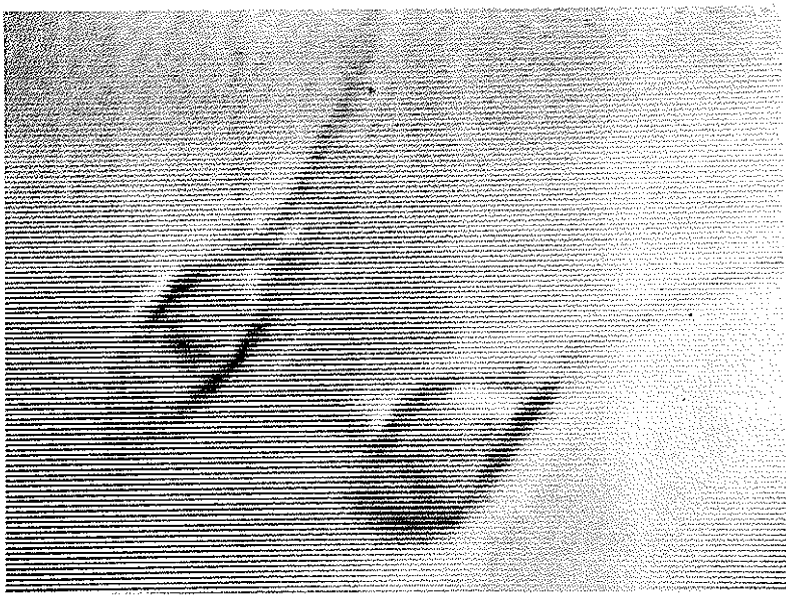

图 5 レーザー顕微鏡でみた翼常精子像

\section{3) 血精液症患者}

血精液症患者 3 例の精液中の赤血球は，いずれも図に 示すごとく正常赤血球がほとんよ゙で, 非糸球体性であっ た（図6)。

\section{4. 考 察}

血尿の原因笑患の診断において，まず重要なことは， その血尿が系球体性か非系球体性（泌尿器科血尿）なの かを鑑別することである。そうすることによって，余分 な侵㹈の大きい検査を省き，診断過程を簡略化できると 考えら机る。例外もあるが，一般的に，系球体性の場合 は属中に変形赤血球がみら㧈，非系球体性の場合は尿中 に正常赤血球がみられる上されている7゙.8っの圂中 の赤血球形態を観察するために，従来より位相差戬微鏡 や走查型電子顕微鏡などが用いられているが7ー97，位 相差顕微鏡は観察にかなりの熟練を必要亡するし，また， 走査型電子顕微鏡は固定などの前処置が煩雑であるため， いずれも、日常診療でのルーチン検查にはなりにくいの が現状である。

一方，尿中変形赤血球は正常赤血球にくらべて小球性 (平均赤血球容積が小さい)であることより，自動血球 計数装犆やフローサイトメトリーを用いて，尿中赤血球 の容積分布を調べる方法が報告されているがい，康中 の非赤血球成分をも一粕に分析してしまう次点があり， また、フローサイトメトリーは非常に商価である。

今回, リアルタイム共焦点型レーザー顕微鏡を用いて 尿中赤血球形態を観察したが，従来の方法に比べて簡便 で，染色や固定の必要性もなく，画像が鮮明で，検査に 要する時間も短く, 得られた結果も位相差顕微鏡や走査 型電子顕微鏡を用いた報告に比べ遜色なかっだ2。以上 より、レーザー顕微鏡を用いた尿中赤血球の形態観察は 血尿の有力な補助診断になり得ると考えられる。

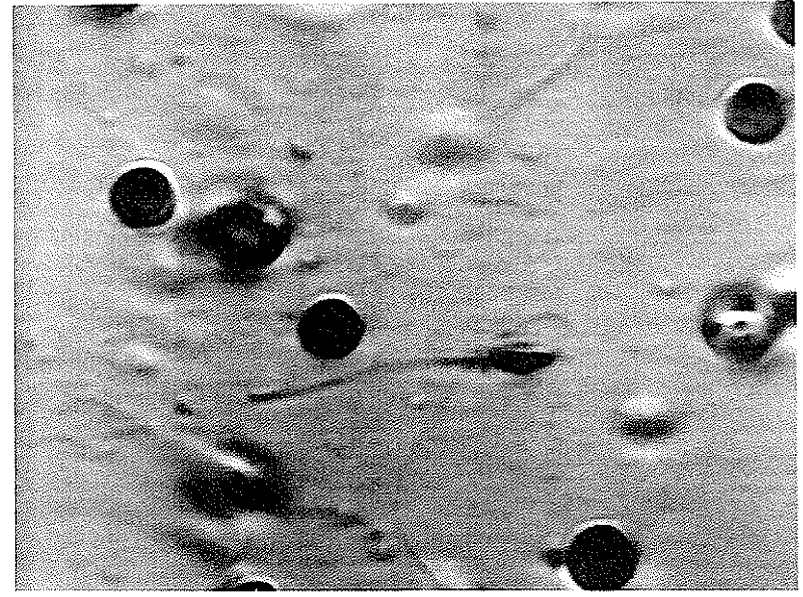

図 6 血精液症のレーザー顕微鏡所見

1440 倍

生きている精子を飯野らがレーザー顕微鏡を用いて観 察して以来 ${ }^{11}$, 当科でもレーザー顕微鏡を用いて精子 の形態を研究している。その結果, 良い精子は頭部が狭 く, 中片が長く, 頭部のアクロゾーム領域の頭部全体に 占める割合が多いなどというようなことが推測されてお り"、さらに研究が進めら机ている。

最近，他社の共焦点レーザー影微鏡苍用いて，他社の 共焦点レーザー顕微鏡を用いて，染色下に細菌バイオ フィルムの観察を行った報告"2がみら扚が，この機 種は我々の使用しているもの上棈造が異なり，蛍光色素 に上る染色が必要でするので，精子など生きているその ままの条件下で観察したい場公には不向きと考えら扟る。 いず㧈にしても，今後，泌尿器科の色々な分野に其焦点 型レーザー顕微鏡が応用されてゆく可能性があると思わ れる。

\section{5. 結 論}

共焦点型レーザー影微鏡は，血尿患者の尿中赤血球形 態ならびに男性不妊症恶者の精子形態の観察に有用であ ると考えられた。

\section{文 献}

1) Hyodo T, Ono K, Koumi T et al : Application of the confocal scanning laser microscope for observing biological specimens: Detection of glomerular bleeding. Nephron 59 : 685-686. 1991.

2) Miyagawa I, Hyodo T, Iino A: Detection of glomerular bleeding by the confocal scanning laser microscope. Akt Urol 24 suppl: 89-91. 1993. 
3）平川真治，山根明文，宮川征男他：診断におけるレ 一ザー顕微鏡の応用. 日本小先泌尿器科科学会雑誌. 2 : 1994 (揭載予定)

4) Sofikitis N, Miyagawa I, Inaga S et al: New morphometric creiteria for normal spermatozoa obtained by confocal scanning laser microscopy : Application in male infertility clinic. $J$ Urol 147 suppl : 322 A (abstract), 1992.

5) Thiel G, Bielmann D, Wegmann $W$ et al: Glomeruläre erythrozyten im urin : Erkennung und Bedeutung. Schweiz Med Wschr 116:790797, 1986

6）石原幸吉，伊藤 拓：血尿を起こす小㫛疾患をどう 診るか：血尿の診かた治しかた，46-52, 金原出版, 1992.

7) Birch DF, Fairley KF : Hematuria : Glomerular or non-glomerular ? Lancet ii : 845-846, 1979

8) Fassett RG, Horgan BA, Mathew $\mathrm{TH}$ : Detection of glomerular bleeding by phasecontrast microscopy. Lancet i : 1432-1434, 1982.

9) Fairley KF, Birch DF : Hematuria : A simple method for identifying glomerular bleeding. Kidney Int 21: 105-108, 1982.

10) Shichiri M, Oowada A, Nishio Y et al : Use of autoanalyser to examine urinary-red-cell morphology in diagnosis of glomerular hematuria. Lancet ii : 781-782. 1986.

11) Lino A, Inaga S, Mio $\mathrm{X}$ : Application of color laser microscope for observing living biological specimens. Cytobios 60:7-10, 1939 .

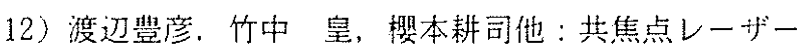
走査顕微鏡による細菌バイオフィルムの観察．第82 回日本泌尿器科学会総会予稿集 : 369, 1984. 